Durhat, G. ve Ökten, C. E. (2020). Kök değerlerin ortaokul Türkçe ders kitaplarındaki erdemler temasıyla ilişkisi. Ana Dili Eğitimi Dergisi, 8(3), 675-693.

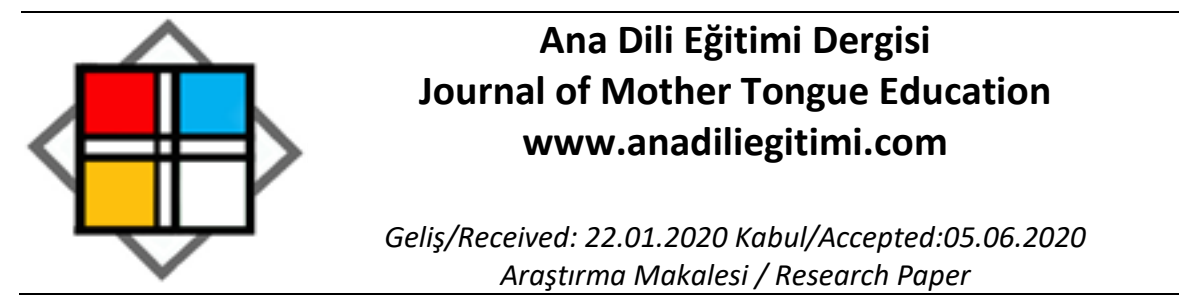

\title{
Kök Değerlerin Ortaokul Türkçe Ders Kitaplarındaki Erdemler Temasıyla İlişkisi
}

\author{
Gözde DURHAT* \\ Celile Eren ÖKTEN ${ }^{* *}$
}

\begin{abstract}
Öz
Eğitim sistemi akademik açıdan başarılı bireyler yetiştirmeyi hedeflemekle birlikte, önceliğini temel değerleri benimsemiş bireyler yetiştirmeye vermektedir. Türkçe dersleri de ders kitaplar aracılı̆ıyla değerleri öğrencilere aktarmakta, dünden getirilenlerle bugüne ve yarınlara ışık tutmaktadır. Bu çalışmanın amacı 2018-2019 eğitim öğretim yılında okutulan Ortaokul Türkçe Ders Kitaplarının Erdemler temasında yer alan kök değerleri tespit etmek ve kök değerlerin temadaki metin ve etkinliklerle ilişkisini ortaya koymaktır. Çalışma doküman incelemesi kapsamında yürütülmüş olup ortaokul Türkçe ders kitaplarında yer alan Erdemler teması araştırmanın inceleme nesnesi olarak belirlenmiştir. Veriler doküman incelemesi, yarı yapılandırılmış görüşme (18 kız, 24 erkek öğrenci), alan taraması kullanılarak toplanmış; verilerin çözümlenmesinde betimsel analiz ve içerik analizi esas alınmıştır. Araştırmayla kök değerlerin dengeli bir dağılımının olmadığı, yardımseverlik ve sevgi değerine sıkça yer verilirken öz denetim ve vatanseverlik değerinin temada yer almadığı sonucuna ulaşılmıştır. Erdemler temasının öğrencilere nasıl bir kişilik kazandırmaya yöneldiği ve kök değerlerin öğrenciler üzerinde nasıl bir etkisinin olduğu tespit edilmiştir.
\end{abstract}

Anahtar Kelimeler: Değerler eğitimi, kök değerler, Erdemler teması.

\begin{abstract}
Relatedness of Root Values to the "Virtues Theme" in Turkish Coursebooks
Abstract

The aim of this study is to determine the fundamental values found in the Secondary Turkish language courseboks, which were studied in 2018-2019 academic year, and also to show the relationship among the fundamental values, texts and activities. The research was conducted through document analysis. The Virtues theme, which was repeated respectively in every grade of Turkish language coursebook, was chosen as an analysis unit. The data were collected through document analysis, literature review, semi-structured interviews (18 females, 24 males); The data were coded and classified with using descriptive analysis and content analysis. In conclusion, the study showed that there was no equal distribution of fundamental values; such as values of helpfulness and love were mentioned more, values of self-control and patriotism were skipped in the theme. It was determined that what type of affect the fundamental values have on the students, and the Virtues theme tends to make the students gain their personalities.
\end{abstract}

Keywords: teaching of values, fundamental values, the theme of Virtues.

\section{Giriş}

Dil, bir toplumu var eden ve varlığını devam ettiren en önemli etmenlerden biridir. Toplum, dil sayesinde kültürünü ve değerlerini gelecek kuşaklara aktarabilir. Yaşanılan çağda uygun görülen veyahut görülmeyen davranışlar yıllar sonrasına dille ulaşabilir. "Sosyal varlık olan insan, hayatında bulunan birçok denklem arasında ahenk yaratmak ve kendi devamlılı̆ını sağlamak amacıyla hem içinde

\footnotetext{
*öğretmen, YL öğrencisi, Yıldız Teknik Üniversitesi, Sosyal Bilimler Enstitüsü, Türkçe Eğitimi, İstanbul, gozde.durhat@gmail.com, ORCID: orcid.org/0000-0002-5068-6210

${ }^{* *}$ Doç. Dr. Yıldız Teknik Üniversitesi, Eğitim Fakültesi, Türkçe Eğitimi, İstanbul, celile@yildiz.edu.tr, ORCID: orcid.org/0000-0002-5541-648X-
} 
bulunduğu kültürle hem dünyadaki diğer toplumlarla bağını bazı kurallar ve kültürel unsurlar aracılığıyla sürdürmektedir. Bu unsurlardan bir tanesi de değerlerdir" (Ergül, 2019: 1). "Değerler, toplumu yapı taşı olan bireylere, nelerin önemli olduğunu, hangi durumlarda nasıl bir davranışın tercih edilmesi gerektiğini kavratmaya çalışan mana yüklü kavramlardır" (Topal, 2019: 248). Değerler her ne kadar toplumsal süreç içerisinde dil yoluyla edinilse de bunların kalıcı hâle gelmesi ve sürdürülebilir olması için sistematik bir öğretime ihtiyaç vardır. Bu ihtiyaç da okulla birlikte giderilir. "ìyi ve erdemli insan olmak, sağlam karakterli bireyler yetiştirmek, okulun ve toplumun en önemli hedeflerinden biridir. Bu hedefi gerçekleştirmek toplumsal kültür değerlerinin gelecek kuşaklara aktarılmasına bağlıdır" (Karatay, 2011: 1441).

Değerler geniş yelpazelidir ve bir sınıflamaya tabi tutulduğunda öznel bir bakış açısıyla değerlendirilir. Evrensel olarak kabul edilen değerler bile zaman zaman tartışma konusu olmaya devam etmektedir. "Bilim dünyasınca en çok kabul gören sınıflama Spranger (1928) tarafından yapılmıştır. Daha sonraki yıllarda bu sınıflandırma Allport ve Verno (1931), Lindzey (1960) tarafından ölçeğe dönüştürülmüştür. Allport ve Vernon, çalışmalarında değerleri; bilimsel, ekonomik, siyasî, sosyal ve dinî olmak üzere kategorize etmişlerdir" (Ecerkale ve Bayrak, 2018: 278). Keskin (2016) Spranger'in de benzer bir sınıflama kullanarak değerleri dinî, ekonomik, estetik, siyasî, sosyal ve teorik olmak üzere altı grupta ele aldığını belirtmiştir. Rokeach (1968) değerler üzerinde en uzun süreli çalışmayı yaparak on sekiz amaç ve on sekiz araç değer ortaya çıkarmıştır. "Schwartz'a ait olan değerler ölçeğinde ise on temel değer yer almıştır: Başarı, evrenselcilik, geleneksellik, güç, güvenlik, hazcllık, iyilikseverlik, öz yönelim, uyarılım, uyma" (Schwartz, 1992; Akt. Keskin, 2016: 1492). Alanyazın incelendiğinde Schwartz ve Rokeach'ın değerler sınıflandırması ölçüt alınarak hazırlanmış tezlere ulaşılmıştır. Bunlara "Bulgular" bölümünde yer verilmiştir.

Eğitim alanında henüz 21. yüzyılda önem kazanan değerler ve normlar, evrensel bir ortak akıl oluşturma çabasının getirisidir. Değerlerin eğitim alanında kendisini göstermesi, UNESCO'nun desteklediği Yaşayan Değerler Eğitimi Programı adı altında BM'nin 1995'teki 50. yıl dönümü kutlamaları için hazırlanan uluslararası bir projeye dayanır. "Yaşayan Değerler Eğitimi adı verilen projede, evrensel değerlerin öğrencilere kazandırılmasında etkinlik temelli yaklaşımlar yaygın olarak kullanılmıştır. 'Daha iyi bir dünya için değerlerimizi paylaşalım.' yaklaşımından yola çıkan proje; iş birliği, özgürlük, mutluluk, dürüstlük, sevgi, alçak gönüllülük, barış, saygı, sorumluluk, sadelik, hoşgörü, birlik olmak üzere 12 evrensel değere odaklanmıştır" (Cihan, 2014: 433).

"Cumhuriyetten günümüze kadar uygulanan Türkçe öğretim programlarında değerlere vurgu yapılmış, Türkçe öğretiminin amaçları içerisinde birtakım değerlere yer verilmiştir" (Mutlu ve Dinç, 2019: 1050). Türkiye'de değerler eğitiminin daha programlı şekilde uygulanmaya başlanması ise MEB Talim Terbiye Kurulu Başkanlığı'nın 2010-2011 eğitim öğretim yılında valiliklere ve tüm ilk ve orta dereceli okullara; değerler eğitimine yönelik faaliyetlerin gerçekleştirilmesi ile ilgili bir yönerge yollamasıyla başlamıştır. Bu yönergede değerler eğitiminin amacı ve kapsamı şu şekilde ifade edilmektedir: "Toplumsal hayatı oluşturan, insanları birbirine bağlayan, geliş̧meyi, mutluluğu ve huzuru sağlayan, risk ve tehditlerden koruyan ahlâkî, insanî, sosyal, manevî değerlerimizin tüm bireylere kazandııımasında en önemli etken eğitimdir. Bu kazanımlarımızın öğrencilerimize aktarılması da değerler eğitimini oluşturmaktadır" (MEB Talim ve Terbiye Kurulu Başkanlığı, 2010).

MEB 2018 yılında 51 müfredat ekseninde bir yenileme çalışması gerçekleştirmiştir. Müfredatlarda yapılan yenileme çalışmalarına ek olarak öğretim programlarının ana felsefesini içeren metinde de güncellemeye gidilmiştir. Daha önceki yıllarda değerler eğitimine verilmeye başlanan önem, bu güncellenmeyle birlikte daha da belirginleşmiştir. Eğitim sisteminin salt bilgi aktarımının ötesinde bir işlevi olduğu vurgulanan metinde, toplumun geleceğini oluşturan bireylerin; birtakım bilgi, beceri ve davranışlarla değerleri bütünleştirerek günlük yaşamına dâhil etmesinin eğitimin temel amacı olduğu ifade edilmiştir. "Eğitim sistemi değerleri kazandırma amacı çerçevesindeki işlevini, öğretim programlarını da kapsayan eğitim programıyla yerine getirir" (MEB, 2018: 4). Değerlerin ayrı bir program veya öğrenme alanı, ünite, konu vb. olarak görülmediği, tam aksine bütün eğitim sürecinin nihai gayesi olduğu, öğretim programlarının her birinde ve her bir biriminde yer alması gerektiği vurgulanarak on kök değer belirlenmiştir. 
"Değerler eğitimi, karakterli, ahlâklı ve kişilik sahibi bireyler yetiştirmeyi amaçlar. Değerlerin çocuğa aktarılması süreci olan değerler eğitiminde, başta aile olmak üzere okul, çevre, medya ve sosyal medya gibi unsurlar etkin rol oynamaktadır" (Deniz ve Karagöl, 2018: 246). Okul, değerlerin sistemli olarak öğrencilere kazandııılmasını ders kitapları vasıtasıyla sağlar. "Türkçe derslerinde yer alan metinler aracılığıyla öğrencilere bu değerlerin kavratılması ve bunları hayatlarında uygulamalarına imkân sağlanması öğrencilere daha etkili ve daha nitelikli bir şekilde değerler eğitiminin verilmesini sağlayacaktır" (Güven, 2014: 89). Öğrencilerin kendisini sorgulamasını sağlayan, dikkat çekici ve merak uyandırıcı, millî ve manevî yönlerini geliştiren nitelikte eserlerin seçilmesi değerlerin öğrenciye daha kolay şekilde aktarılması açısından oldukça önemlidir.

Türkçe Öğretim Programı́nın Temalar ve Konu Önerileri başlığı altında ders kitaplarında yer alması istenen üç zorunlu, on üç seçmeli tema bulunmaktadır. Bu seçmeli ve zorunlu temaların konu önerilerinde kök değerlere yer verilmiştir. Tablo 1 incelendiğinde MEB'in kök değerleri daha çok Erdemler temasında işlenmesini önerdiği görülmektedir. Erdemler temasındaki konu önerileri altı kök değer içermekle birlikte her bir konu da bir değeri içermektedir. Diğer zorunlu temalarda ise kök değerlerden sadece vatanseverliğe yer verilmiştir. Zorunlu tema olması nedeniyle her sınıf seviyesinde takip edilebilmesi, Erdemler ile değerler arasındaki ilişki ve temalardaki konu dağılımları göz önünde bulundurulduğunda Erdemler temasıyla daha sistemli bir değerler eğitimi verilebileceği düşünülmektedir. Bu sebeple zorunlu temalar içerisinde Erdemler teması seçilmiş ve kök değerlerle arasındaki ilişki incelenmiştir.

Tablo 1.

2018 Türkçe Öğretim Programı Zorunlu Temalar ve Konu Önerileri

\section{ERDEMLER}

ahlâk, alçak gönüllülük, azim, cömertlik, dayanışma, dostluk, dürüstlük, güven, iyilikseverlik, kardeşlik, merhamet, paylaşma, sabır, sadakat, saygı, sevgi, sılayırahim, vefa, vicdanlı olmak, yardımlaşma vb. MiLLî KÜLTÜRÜMÜZ

aile, bayrak, büyüklerimiz, dinî bayramlar, gelenekler, geleneksel sporlar, insan ilişkileri, kültürel miras, mekânlar, millî bayramlar, şehirlerimiz, sıla, tarihî mekânlar, tarihî şahsiyetler, tarihî eserlerimiz, Türkçe, vakıf kültürü, vatan, yurdumuz vb.

MILLÎ MÜCADELE VE ATATÜRK

15 Temmuz, Atatürk, Çanakkale, cesaret, Cumhuriyet, fedakârlık, gazilik, İstiklâl Marşı, kahramanlık, Kut'ül Amare, millî egemenlik, millî irade, millî kimlik, millî mücadele, Sarıkamış Harekâtı, şehitlik, vatanseverlik vb.

Araştırmayla Erdemler temasındaki metin (12 okuma, 4 dinleme metni) ve etkinliklerin Türkçe Öğretim Programı'nda (2018) "adalet, dostluk, dürüstlük, öz denetim, sabır, saygı, sevgi, sorumluluk, vatanseverlik ve yardımseverlik" olarak belirlenen on kök değerle ilişkisi, değerlerin/kök değerlerin kazanımlarda ne düzeyde yer aldığı incelenmiştir. Verilerin çeşitlendirilmesi amacına hizmet edip araştırmanın geçerliğini artırmak için İstanbul Pendik Nurettin Topçu İmam Hatip Ortaokulunda 5, 6, 7 ve 8. sınıf seviyelerinde öğrenim gören 18 kız, 24 erkek öğrenci seçkisiz olarak belirlenmiş, öğrencilerle yarı yapılandırılmış görüşmeler gerçekleştirilmiştir. Bu araştırmayla şu sorulara cevap aranmıştır:

1. Erdemler temasında kök değerler nasıl bir dağılıma sahiptir?

2. Temada öğrencilere hangi değerlerin kazandırılması amaçlanmıştır?

3. Kök değerlerin bulunduğu metin ya da etkinlikler söz konusu değerin kazanılması konusunda yeterli düzeyde midir?

4. Kök değerler, etkinliklerde ne sıklıkta işlenmektedir?

MEB, 2018 yılında değişen müfredatın ana metninde yaptığı güncelleme ile kök değerlere vurgu yapmış ve eğitim sisteminin temel amacının yalnızca bilgi ve beceriden ibaret olmadığını, değerleri benimsemiş bireyler yetiştirmenin de hedeflenmekte olduğunu belirtmiş̧ir ancak öğretim programında yer alan on kök değerin; temalardaki yeri, dağılımı, kazanımlardaki sıklığı, kök değerlerin dışında hangi değerlere yer verildiği, bunların öğrencilerin üzerinde nasıl bir etkiye sahip olduğuyla ilgili 
çalışmalar oldukça az sayıdadır. Bu çalışmanın getirdiği bulgu ve öneriler tartışmaya açık olup bu alanla ilgili yeni çalışmaların yapılmasına zemin hazırlaması hedeflenmektedir.

\section{Araştırmanın Modeli}

\section{Yöntem}

Araştırma, nitel araştırma desenlerinden doküman incelemesi kapsamında yürütülmüştür. Buna göre Ortaokul ve İmam Hatip Ortaokulu Türkçe Ders Kitapları Erdemler temasında yer alan kök değerler incelenmiştir. "Doküman incelemesi, araştırılması hedeflenen olgu ve olgular hakkında bilgi içeren yazılı materyalleri kapsar. Nitel araştırmada doküman incelemesi tek başına bir veri toplama yöntemi olabileceği gibi diğer veri toplama yöntemleri ile birlikte de kullanılabilirler" (Yıldırım ve Şimşek, 2018: 189). Araştırmanın geçerliğini artırmak için 2018-2019 eğitim öğretim yılında öğrenim gören, Pendik Nurettin Topçu İmam Hatip Ortaokulu öğrencileriyle (18 kız, 24 erkek) yarı yapılandırılmış görüşmeler gerçekleştirilmiştir. Öğrenciler, her sınıf seviyesini temsil edecek şekilde 19 sınıf içerisinden seçkisiz olarak belirlenmiştir.

\section{Çalışma Dokümanı}

Araştırmada amaçlı örnekleme yöntemlerinden biri olan ölçüt örneklemeden yararlanılmıştır. "Bu örnekleme yöntemindeki temel anlayış önceden belirlenmiş bir dizi ölçütü karşılayan bütün durumların çalışılmasıdır. Ölçüt araştırmacı tarafından oluşturulur ya da daha önceden hazırlanmış ölçütler listesi kullanılabilir" (Yıldırım ve Şimşek, 2018: 122). MEB Yayınları Ortaokul ve İmam Hatip Ortaokulu Türkçe Ders Kitaplarında zorunlu tema olarak yer alan Erdemler teması, Türkçe Dersi Öğretim Programı Kök Değerler listesi ölçüt alınarak incelenmiştir.

\section{Veri Toplama Araçları}

Araştırmada ulaşılan sonuçların birkaç yönden kontrolünü yaparak çalışmayı değerli kılmak için doküman incelemesi, yarı yapılandırılmış görüşme ve alan taramasından yararlanılmıştır. Zorunlu tema olan Erdemler temasının her sınıfta takip edilebilmesi, daha geçerli ve kapsamlı bir veri elde edebilmek için 5. sınıf Türkçe ders kitabı (Haykır vd., 2018), 6. sınıf Türkçe ders kitabı (Ceylan vd., 2018), 7. sınıf Türkçe ders kitabı (Kır, Kırman ve Yağız, 2018) ve 8. sınıf Türkçe ders kitabında (Mete vd., 2018) yer alan Erdemler temasındaki kök değerler, Türkçe Dersi Öğretim Programı'ndaki (2018) kök değerler listesinden yararlanılarak çözümlenmiştir. Değerler eğitimi ve Erdemler temasıyla ilgili alan taraması yapılıp eksiklikler ve uzman görüşleri tespit edilmiştir.

\section{Verilerin Toplanması ve Analizi}

Araştırmada verileri doküman incelemesi yoluyla toplanmıştır. Toplanan veriler, betimsel analiz ve içerik analizine göre çözümlenmiştir. "Betimsel analizde amaç, elde edilen bulguları düzenlenmiş ve yorumlanmış bir biçimde okuyucuya sunmaktır. Bu amaçla elde edilen veriler, önce sistematik ve açık bir biçimde betimlenir. Daha sonra yapılan bu betimlemeler açıklanır ve yorumlanır; neden sonuç ilişkileri irdelenir ve birtakım sonuçlara ulaşılır" (Yıldııım ve Şimşek, 2018: 239-240). Erdemler temasındaki metin ve etkinlikler Türkçe Dersi Öğretim Programı Kök Değerler listesine göre çözümlenmiştir. Bu bağlamda temadaki metin ve etkinliklerde kök değerlere ne sıklıkta yer verildiği, kök değerlerin nasıl bir dağııım gösterdiği ve öğrencilerin değerlerle ilgili nasıl bir kazanım elde ettiğiyle ilgili betimlemeler yapılmış, bunlar neden sonuç çerçevesinde yorumlanmıştır. "Betimsel analizde özetlenen ve yorumlanan veriler, içerik analizinde derin bir işleme tabi tutulur ve betimsel bir yaklaşımla fark edilemeyen kavram ve temalar bu analiz sonucu keşfedilebilir" (Yıldırım ve Şimşek, 2018: 242).

İçerik analizi kapsamında temada yer alan metin ve etkinlikler incelenerek kodlamalar yapılmıştır. Araştırma kapsamında yapılmış olan kodlamanın tutarlıı̆ğını belirlemek için, incelenen tüm metin ve etkinlikler altı hafta arayla iki kere kodlanmıştır. Bu sayede araştırmaçını kendi içindeki tutarlıığı da test edilmiştir. Kodlamalar neticesinde "değerler" ve "kök değerler" olmak üzere iki tema belirlenmiştir. Belirlenen temaların altında yer alan veriler, bulgular bölümünde tablo ve grafik hâlinde sunulmuş ve yorumlanmıştır. 42 öğrenciyle gerçekleştirilen yarı yapılandırılmış görüşmeler yazıya 
aktarılmış, veriler incelenip kodlamalar yapılarak belirli temalara ulaşılmış ve bulgular bölümünde bu veriler yorumlanmıştır.

Alan taramasına yönelik olarak Türkçe ders kitaplarının değerler eğitimiyle ilişkisini inceleyen tezler araştırılmıştır. Değerlerin geçmişten günümüze ders kitaplarına nasıl yansıdığı, hangi değerlerin kitaplarda sıklıkla yer aldığı tespit edilmiştir.

\section{Bulgular}

Türkçe ders kitaplarının her bir temasında üç okuma, bir dinleme/izleme metni yer almaktadır. Araştırma kapsamında Erdemler temasında bulunan 12 okuma metni, 4 dinleme izleme metni incelenmiş, serbest okuma metinleri araştırmaya dâhil edilmemiştir. Tablo 2 'de temada yer alan metinler verilmiştir.

Tablo 2.

Sınıf Düzeyine Göre Erdemler Temasında Yer Alan Metinleri

\begin{tabular}{|c|c|c|c|}
\hline Sinif & Metin & Yazar & Metin Türü \\
\hline $\begin{array}{l}\text { 志 } \\
\bar{n} \\
\text { in }\end{array}$ & $\begin{array}{l}\text { Güvercin } \\
\text { Karagöz ile Hacivat- İncelik } \\
\text { Püf Noktası } \\
\text { Adsız Çeşme (Dinleme/İzleme Metni) } \\
\text { Tema Değerlendirme Soruları / Güler Yüze ve Gülmeye } \\
\text { Dair }\end{array}$ & $\begin{array}{l}\text { Beydaba } \\
\text { Suat Batur } \\
\text { Süleyman Bulut } \\
\text { Hasan Âli Yücel } \\
\text { Şevket Rado }\end{array}$ & $\begin{array}{l}\text { Fabl } \\
\text { Tiyatro } \\
\text { Hikâye } \\
\text { Şiir } \\
\text { Sohbet }\end{array}$ \\
\hline $\begin{array}{l}\frac{4}{\bar{\Xi}} \\
\bar{n} \\
0\end{array}$ & $\begin{array}{l}\text { Vermek Çoğalmaktır } \\
\text { Sevgi Diyen Çağlar Aşar } \\
\text { Gümüş Kanat } \\
\text { Balıkçıl (Dinleme/i̇zleme Metni) } \\
\text { Tema Değerlendirme Soruları / Güler Yüze ve Gülmeye } \\
\text { Dair }\end{array}$ & $\begin{array}{l}\text { Göksu Birol } \\
\text { Bestami Yazgan } \\
\text { Cahit Uçuk } \\
\text { Jean de La Fontaine } \\
\text { Şevket Rado }\end{array}$ & $\begin{array}{l}\text { Hikâye } \\
\text { Şiir } \\
\text { Hikâye } \\
\text { Fabl } \\
\text { Sohbet }\end{array}$ \\
\hline 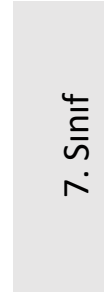 & $\begin{array}{l}\text { Tahta Bisiklet } \\
\text { Kaplumbağayla İki Ördek } \\
\text { Kızgın Bir Lira } \\
\text { Akıllı Evlat (Dinleme/İzleme Metni) } \\
\text { Tema Değerlendirme Soruları / Güler Yüze ve Gülmeye } \\
\text { Dair }\end{array}$ & $\begin{array}{l}\text { Hidayet Karakuş } \\
\text { Jean de La Fontaine } \\
\text { I. Zeki Burdurlu } \\
\text { Naki Tezel } \\
\text { Şevket Rado }\end{array}$ & $\begin{array}{l}\text { Mektup } \\
\text { Fabl } \\
\text { Anı } \\
\text { Masal } \\
\text { Sohbet }\end{array}$ \\
\hline $\begin{array}{l}\stackrel{4}{\Xi} \\
\sim \\
\infty \\
\infty\end{array}$ & $\begin{array}{l}\text { Yunus Emre'nin Mezarları } \\
\text { Gülü İncitme Gönül } \\
\text { Emine Teyzenin Çilek Reçeli } \\
\text { Yürekdede ile Padişah (Dinleme/İzleme Metni) } \\
\text { Tema Değerlendirme Soruları - Merhamet }\end{array}$ & $\begin{array}{l}\text { Nezihe Araz } \\
\text { Bestami Yazgan } \\
\text { Miyase Sertbarut } \\
\text { Cahit Zarifoğlu } \\
\text { Nurettin Topçu }\end{array}$ & $\begin{array}{l}\text { Gezi Yazısı } \\
\text { Şiir } \\
\text { Hikâye } \\
\text { Hikâye } \\
\text { Deneme }\end{array}$ \\
\hline
\end{tabular}

Bu metin, etkinlik ve Tema Sonu Değerlendirme sorularının içerik analizi yapıldığında metinlerin içerdiği ağırlıklı değer/kök değerler Tablo 3'te belirtilmiştir.

Tablo 3.

Erdemler Temasındaki Metinler ve Içerdiği Değerler - Kök Değerler

\begin{tabular}{lll}
\hline Sınıf & Metinler & Değerler - Kök Değerler \\
\hline \multirow{3}{*}{ 5. Sınıf } & Güvercin & Birlik, yardımseverlik, fedakârlık \\
& Karagöz ile Hacivat- İncelik & Görgülü olmak, sevgi \\
& Püf Noktası & Sabır, saygı, birlik \\
& Adsız Çeşme & Yardımseverlik, cömertlik, alçak gönüllülük, hoşgörü, iyilik \\
& Tema Sonu Değerlendirme & Güler yüzlü olmak, hoşgörü, birlik, çalışkanlık, iyilik \\
\hline
\end{tabular}




\begin{tabular}{|c|c|c|}
\hline \multirow{5}{*}{ 6. Sinif } & Vermek Çoğalmaktır & $\begin{array}{l}\text { Fedakârlık, yardımseverlik, cömertlik, saygı, adalet, dostluk, } \\
\text { sevgi, vefa, alçak gönüllülük }\end{array}$ \\
\hline & Sevgi Diyen Çağlar Aşar & Sevgi, hoşgörü \\
\hline & Gümüş Kanat & Fedakârlık, yardımseverlik, sevgi \\
\hline & Balıkçıl & Hoşgörü, kanaatkârlık, dürüstlük, sabır \\
\hline & Tema Sonu Değerlendirme & Güler yüzlü olmak \\
\hline \multirow{5}{*}{ 7. Sinif } & Tahta Bisiklet & Sevgi \\
\hline & Kaplumbağayla İki Ördek & Dostluk, yardımseverlik \\
\hline & Kızgın Bir Lira & Dürüstlük \\
\hline & Akıllı Evlat & Misafirperverlik, dürüstlük, alçak gönüllülük, yardımseverlik \\
\hline & Tema Sonu Değerlendirme & Güler yüzlü olmak, dostluk \\
\hline \multirow{4}{*}{ 8. Sinif } & $\begin{array}{l}\text { Yunus Emre'nin Mezarları } \\
\text { Gülü İncitme Gönül }\end{array}$ & $\begin{array}{l}\text { Dürüstlük, saygı, sevgi, vefa, sorumluluk, alçak gönüllülük } \\
\text { Sevgi, hoşgörü, yardımseverlik, güven }\end{array}$ \\
\hline & Emine Teyzenin Çilek Reçeli & Dayanışma, saygı, yardımseverlik \\
\hline & Yürekdede İle Padişah & Cömertlik, misafirperverlik, saygı, sevgi, yardımseverlik \\
\hline & Tema Sonu Değerlendirme & Merhamet, adalet, yardımseverlik \\
\hline
\end{tabular}

Tablo 3'te yer alan değer ve kök değerler, Türkçe Öğretim Programı Kök Değerler listesine göre düzenlendiğinde sınıf bazında şu bulgular elde edilmiştir:

Tablo 4.

5. Sınıf Ders Kitabı Erdemler Temasında Yer Alan Kök Değerler

\begin{tabular}{|c|c|c|c|c|c|c|c|c|c|c|c|}
\hline Metin & $\frac{\frac{U}{0}}{\frac{\pi}{0}}$ & 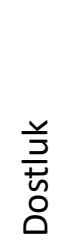 & 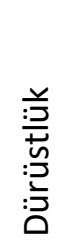 & 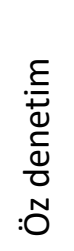 & $\frac{\overline{0}}{\sqrt[0]{n}}$ & 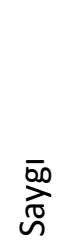 & 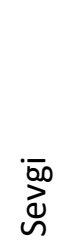 & 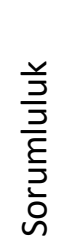 & 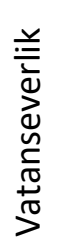 & 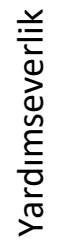 & $\begin{array}{l}\mathbb{E} \\
\frac{\varepsilon}{\pi} \\
\frac{\pi}{0} \\
\circ\end{array}$ \\
\hline \multicolumn{12}{|l|}{ Güvercin } \\
\hline & - & + & - & - & - & - & - & - & - & + & 2 \\
\hline Karagöz ve Hacivat & - & - & - & - & - & - & + & - & - & - & 1 \\
\hline Püf Noktası & - & - & - & - & + & + & - & - & - & - & 2 \\
\hline Adsız Çeşme & - & - & - & - & - & - & - & - & - & + & 1 \\
\hline $\begin{array}{l}\text { Tema Sonu } \\
\text { Değerlendirme }\end{array}$ & - & - & - & - & - & - & - & - & - & - & - \\
\hline Toplam & - & 1 & - & - & 1 & 1 & 1 & - & - & 2 & 6 \\
\hline
\end{tabular}

5. sınıf Erdemler temasındaki metin ve etkinliklerde 5 farklı kök değer bulunmaktadır, yardımseverlik kök değeri ise iki metinde geçmektedir. Güvercin metninde dostluk ve yardımseverlik; Karagöz ve Hacivat metninde sevgi; Püf Noktası'nda sabır ve saygı; Adsız Çeşme'de yardımseverlik kök değerleri tespit edilmiştir. Adsız Çeşme metninden sonra yer alan dört etkinlikte ise salt iyilik kavramı üzerinde durulmuştur. Ayrıca etkinliklerden birinde Mevlânâ'nın 7 öğüdüne yer verilerek cömertlik, yardımseverlik, şefkat, merhamet, alçak gönüllülük ve hoşgörü değerlerine de dikkat çekilmesi sağlanmıştır. Bu sebeple temanın değerler eğitimine dikkat çeken en belirgin metni Adsız Çeşme'dir. Tema Sonu Değerlendirmede (TSD) Şevket Rado'ya ait Güler Yüze ve Gülmeye Dair metnine yer verilmiştir fakat bu metinde kök değerlere rastlanmamıştır. Etkinliklerde de kök değerlerin yer almadığı 
fakat birlik, çalışkanlık, hoşgörü ve iyilik gibi değerlere yer verildiği görülmektedir. Temada yer almayan kök değerler ise adalet, dürüstlük, öz denetim, sorumluluk, vatanseverliktir.

6. sınıf Türkçe ders kitabı Erdemler temasında yer alan metin ve kök değerler Tablo 5'te gösterilmiştir.

Tablo 5.

6. Sınıf Ders Kitabı Erdemler Temasında Yer Alan Kök Değerler

\begin{tabular}{|c|c|c|c|c|c|c|c|c|c|c|c|}
\hline Metin & $\frac{\frac{\pi}{\frac{\pi}{\pi}}}{\frac{\pi}{2}}$ & 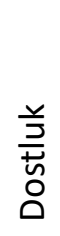 & 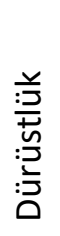 & 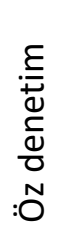 & $\begin{array}{l}\frac{\overline{0}}{0} \\
\stackrel{0}{n}\end{array}$ & $\begin{array}{l}\overline{00} \\
\stackrel{\overline{0}}{n}\end{array}$ & 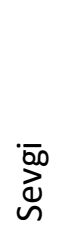 & 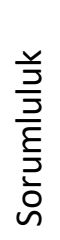 & 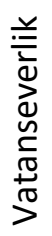 & 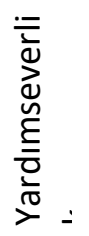 & $\begin{array}{l}\Phi \\
\frac{E}{\pi} \\
\frac{\pi}{0} \\
\circ\end{array}$ \\
\hline \multicolumn{12}{|l|}{ Vermek Çoğalmaktır } \\
\hline & + & + & - & - & - & + & + & - & - & + & 5 \\
\hline Sevgi Diyen Çağlar Aşar & - & - & - & - & - & - & + & - & - & - & 1 \\
\hline Gümüş Kanat & - & - & - & - & - & - & + & - & - & + & 2 \\
\hline Balıkçıl & - & - & + & - & + & - & - & - & - & - & 2 \\
\hline Tema Sonu & & & & & & & & & & & \\
\hline Değerlendirme & - & - & - & - & - & - & - & - & - & - & - \\
\hline Toplam & 1 & 1 & 1 & - & 1 & 1 & 3 & - & - & 2 & 10 \\
\hline
\end{tabular}

6. sınıf Erdemler temasında 7 farklı kök değer bulunmaktadır; yardımseverlik iki, sevgi değeri ise üç metinde geçmektedir. Vermek Çoğalmaktır metninde adalet, dostluk, sevgi, saygı ve yardımseverlik; Sevgi Diyen Çağlar Aşar metninde sevgi; Gümüş Kanat metninde sevgi ve yardımseverlik; Balıkçıl metninde dürüstlük ve sabır kök değerleri tespit edilmiştir. TSD'de Şevket Rado'ya ait Güler Yüze ve Gülmeye Dair metnine yer verilmiştir. Değerlerin en belirgin olarak işlendiği metin Vermek Çoğalmaktır metnidir. Metin sonrası etkinlikler de birçok değere yer verildiği görülmüştür. Temada yer almayan değerler öz denetim, sorumluluk ve vatanseverliktir.

7. sınıf Türkçe ders kitabı Erdemler temasında yer alan metin ve kök değerler Tablo $6^{\prime}$ da gösterilmiştir.

Tablo 6.

7. Sınıf Ders Kitabı Erdemler Temasında Yer Alan Kök Değerler

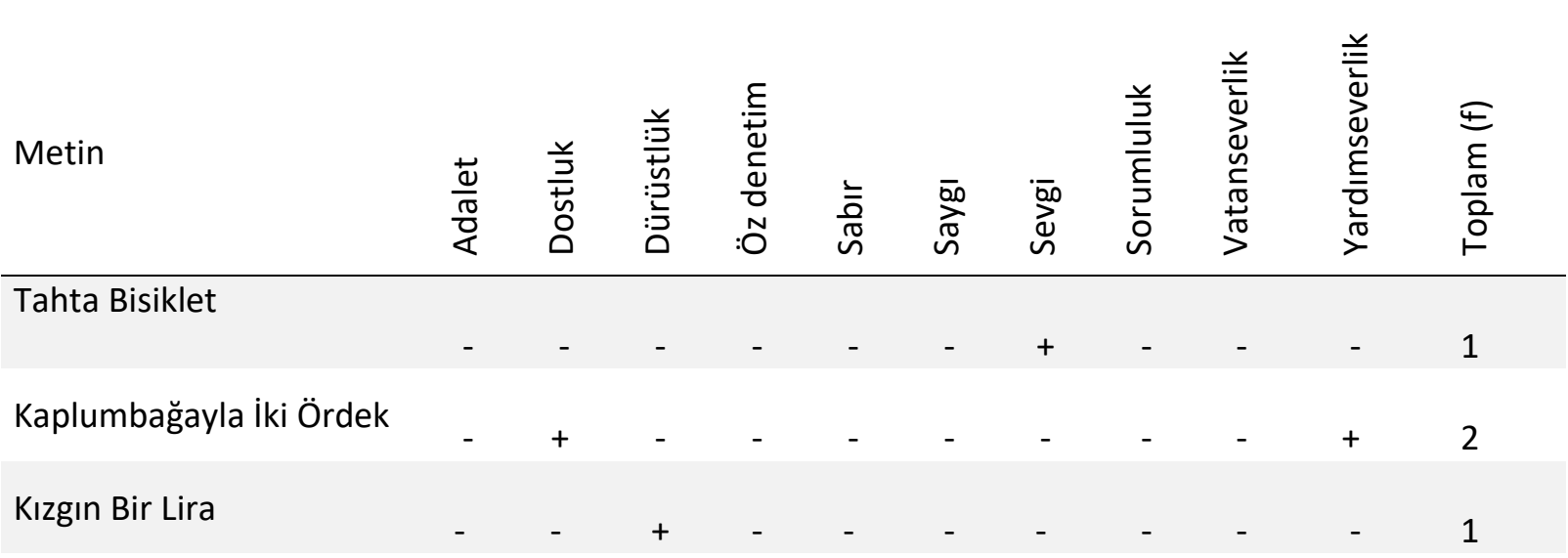




\begin{tabular}{|c|c|c|c|c|c|c|c|c|c|c|c|}
\hline Akıllı Evlat & - & - & + & - & - & - & - & - & - & + & 2 \\
\hline $\begin{array}{l}\text { Tema Sonu } \\
\text { Değerlendirme }\end{array}$ & - & + & - & - & - & - & - & - & - & - & 1 \\
\hline Toplam & - & 2 & 2 & - & - & - & 1 & - & - & 2 & 7 \\
\hline
\end{tabular}

7. sınıf Erdemler temasındaki metin ve etkinliklerde 4 farklı kök değer bulunmaktadır; yardımseverlik, dostluk ve dürüstlük değerleri farklı metinlerde ikişer kez geçmektedir. Tahta Bisiklet metninde sevgi; Kaplumbağayla iki Ördek metninde dostluk ve yardımseverlik; Kızgın Bir Lira metninde dürüstlük; Akıllı Bir Lira metninde dürüstlük ve yardımseverlik kök değerleri tespit edilmiştir. TSD'de 5 ve 6. sınıf TSD'de de yer verilen Şevket Rado'ya ait Güler Yüz ve Gülmeye Dair metni bulunmaktadır. Aynı zamanda etkinliklerde dostluk kök değerine yer verilmiştir. Temada yer almayan değerler adalet, öz denetim, sabır, saygı, sorumluluk, vatanseverliktir.

8. sınıf Türkçe ders kitabı Erdemler temasında yer alan metin ve kök değerler Tablo 7'de gösterilmiştir.

Tablo 7.

8. Sınıf Ders Kitabı Erdemler Temasında Yer Alan Kök Değerler

\begin{tabular}{|c|c|c|c|c|c|c|c|c|c|c|c|}
\hline Metin & $\frac{\frac{\pi}{U}}{\frac{\pi}{0}}$ & $\begin{array}{l}\frac{y}{\partial} \\
\frac{\hbar}{\check{n}} \\
\stackrel{0}{0}\end{array}$ & 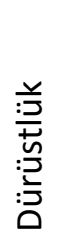 & 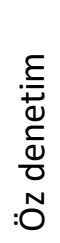 & $\frac{\overline{0}}{\sqrt[0]{0}}$ & 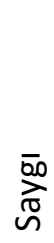 & 岂 & $\begin{array}{l}\frac{y}{J} \\
\frac{\partial}{E} \\
\frac{D}{\partial} \\
\text { v }\end{array}$ & 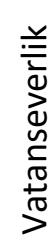 & 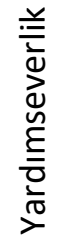 & $\begin{array}{l}\Phi \\
E \\
\frac{E}{0} \\
\frac{0}{0} \\
\vdash\end{array}$ \\
\hline \multicolumn{12}{|l|}{ Yunus Emre'nin Mezarları } \\
\hline & - & - & + & - & - & + & + & + & - & - & 4 \\
\hline Gülü İncitme Gönül & - & - & - & - & - & - & + & - & - & + & 2 \\
\hline Emine Teyzenin Çilek Reçeli & - & - & - & - & - & + & - & - & 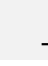 & + & 2 \\
\hline Yürekdede ile Padişah & - & - & - & - & - & + & + & - & - & + & 3 \\
\hline Tema Sonu Değerlendirme & + & - & - & - & - & - & - & - & - & + & 2 \\
\hline Toplam & 1 & - & 1 & - & - & 3 & 3 & 1 & - & 4 & 13 \\
\hline
\end{tabular}

8. sınıf Erdemler teması kök değerlerin en fazla bulunduğu sınıf seviyesidir. 6 farklı kök değere yer verilmiştir. Yardımseverlik dört, sevgi ve saygı değeri ise üç metinde geçmektedir. Yunus Emre'nin Mezarları metninde dürüstlük, sorumluluk, sevgi ve saygı; Gülü Incitme Gönül'de sevgi, yardımseverlik; Emine Teyzenin Çilek Reçeli metninde saygı, yardımseverlik; Yürekdede ile Padişah metninde saygı, sevgi ve yardımseverlik; TSD etkinliklerinde ise adalet ve yardımseverlik kök değerleri tespit edilmiştir. TSD'de Nurettin Topçu'ya ait Merhamet metnine yer verilmiştir. Temada yer almayan değerler dostluk, öz denetim, sabır ve vatanseverliktir.

Temada kök değerlerin haricinde yer alan değerler Tablo 3'te gösterilmiştir. Buna göre 5. sınıfta birlik (3) değeri ön plana çıkmakla birlikte fedakârlık, görgülü olmak, cömertlik, alçak gönüllülük, güler yüzlü olmak ve hoşgörü; 6. sınıfta fedakârlık(2), hoşgörü(2), cömertlik, güler yüzlü olmak ve kanaatkârlık; 7. sınıfta misafirperverlik, alçak gönüllülük, güler yüzlü olmak; 8. sınıfta ise vefa, alçak gönüllülük, hoşgörü, güven, dayanışma, cömertlik, misafirperverlik ve merhamet değerleri tespit edilen diğer değerlerdir. Buna göre Erdemler temasında on kök değerden sekizine yer verildiği görülmüştür: 
Adalet (f:2), dostluk (f:4), dürüstlük (f:4), sabır (f:2), saygı (f:5), sevgi (f:8), sorumluluk (f:1), yardımseverlik ( $f: 10)$. Öz denetim ve vatanseverlik değerleri ise Erdemler temasında yer almamaktadır. Yardımseverlik kök değeri en fazla yüzdelik paya sahip olan kök değerdir.

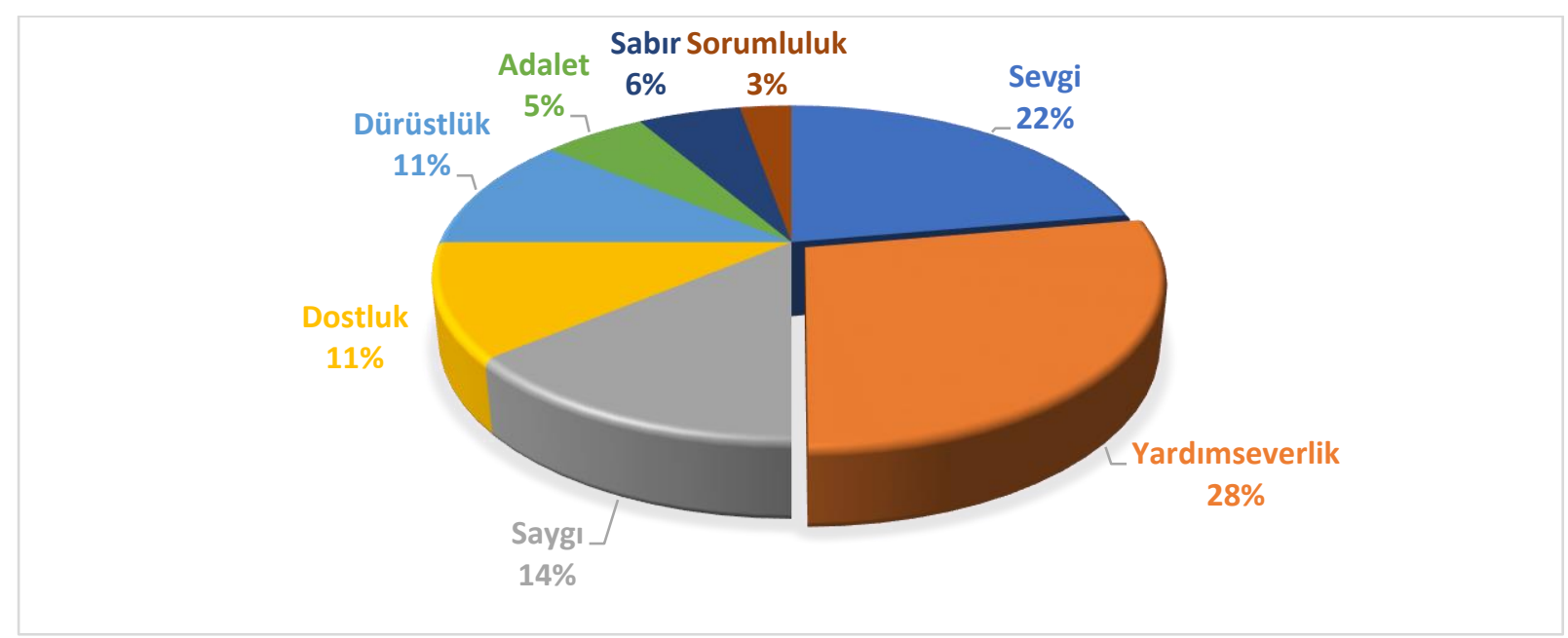

Şekil 1. Erdemler Temasında (5, 6, 7, 8) Yer Alan Kök Değerlerin Yüzdelik Dağılımı

Kök değer olmamasına rağmen cömertlik, birlik, hoşgörü, alçak gönüllülük, güler yüzlülük değerleri de metin ve etkinliklerde sıkça görülmektedir. Türkçe Öğretim Programı́nda kök değerlerin ilişkili olduğu alt değerlerle birlikte alınabileceği ifade edilmiştir fakat bu değerlerin ne olduğu programda yer almamaktadır. Bu sebeple tespit edilen değerlerin hangi kök değer ile ilişkili olduğu açık değildir. Dikkat çeken bir diğer nokta ise 5, 6 ve 7. sınıf Tema Sonu Değerlendirmede Şevket Rado'ya ait Güler Yüz ve Gülmeye Dair metnine yer verilmiş olmasıdır. Temadaki metinlerin birçoğu somutlaştırmaya imkân tanımaktadır fakat metin sonrası etkinlikler uygulamaya dönük değildir. Bu da öğrencinin, değerleri günlük hayatla ilişkilendirebilmesine daha az olanak sağlamaktadır.

UNESCO tarafından Yaşayan Değerler Eğitimi Programı'nda 12 evrensel değer benimsenmiştir. MEB Talim ve Terbiye Başkanlığınca hazırlanmış olan öğretim programında ise evrensel olarak verilen on iki değerden dördü (dürüstlük, saygı, sevgi, sorumluluk) yer almaktadır. Bunun nedenleri üzerinde durduğumuzda her milletin kendine göre öncelikli tuttuğu değerleri vardır ve kök değerlerin haricinde diğer evrensel değerlere de Türkçe ders kitaplarında yer verilmektedir, verilmelidir. Hatta bazı evrensel değerler (alçak gönüllülük, birlik, hoşgörü) Erdemler temasında, kök değerlerden daha sık şekilde ele alınmaktadır. Evrensel değerlerle ortak olan dört değer bulunmaktadır. Bunlardan saygı ve sevgi temada çokça ele alınmaktayken sorumluluk ve dürüstlük geri planda kalmaktadır.

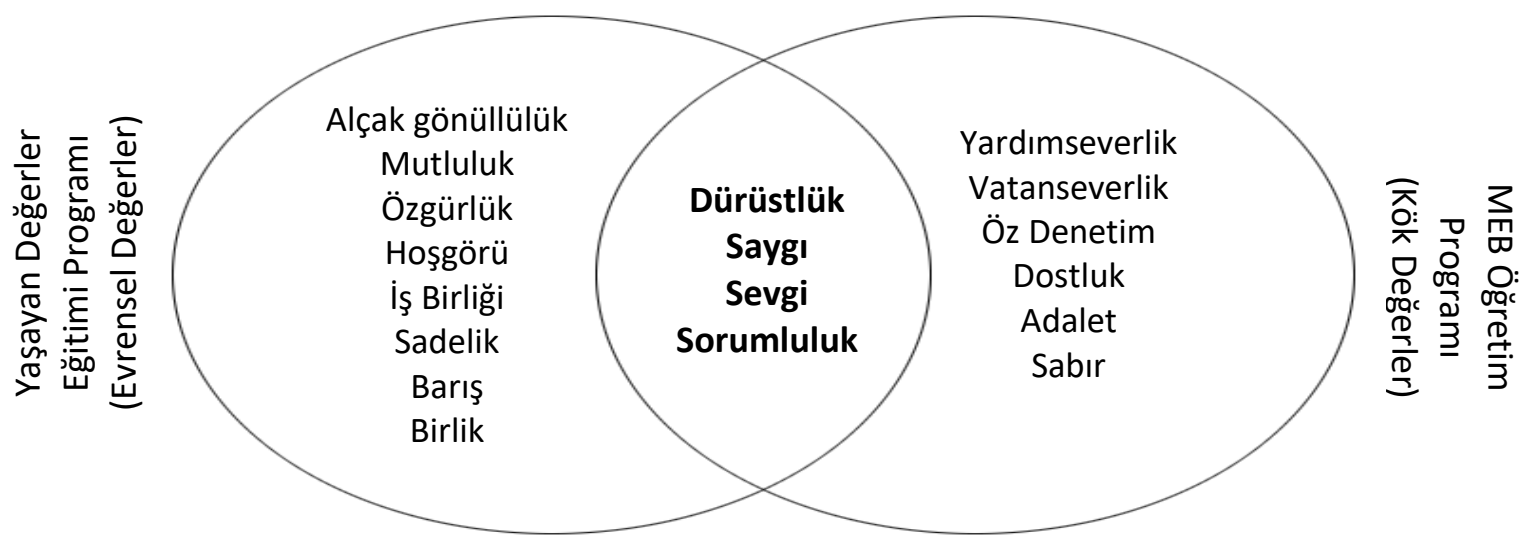

Şekil 2. Evrensel Değerler ile Kök Değerlerin Karşılaştırılması 
Erdemler temasındaki metin ve etkinliklerde yer alan değerlerin öğrenciler (18 kız, 24 erkek) üzerindeki etkilerine yönelik olarak üç açık, üç kapalı uçlu sorudan oluşan yarı yapılandırılmış görüşmeler gerçekleştirilmiş, görüşmeler neticesinde şu çıkarımlarda bulunulmuştur:

Öğrencilerin arkadaş seçiminde kendi değer yargıları etkili olduğu kadar ebeveynlerinin de rolü büyüktür. Öğrencilerin büyük çoğunluğu (f:33), ailelerinin arkadaş seçimlerine müdahil olduklarını belirtmişlerdir. Arkadaş seçimlerinde özellikle sevgi (f:39), dürüstlük (f:36), yardımseverlik (f:33), alçak gönüllülük (f:28), empati (f:12), cömertlik (f:10) belirleyici değerlerdir. Öğrencilerin bir kısmı (f:9) toplumsal kurallara göre hareket ettiğini düşünmemektedir. Bu öğrencilerin 6'sı 7. sınıf öğrencisi, 3'ü 8. sınıf öğrencisidir. Büyüklerinin öğütlerini önemseyen öğrenci sayısı fazladır, bir kısmı (f:12) ise sıkıcı bulmaktadır. Sıkııı bulanların ifadelerinden, büyüklerinin rol model olamamasından dolayı bu tutumu sergiledikleri belirlenmiştir. Niçin ahlâklı olmamız gerektiğiyle ilgili soruya ise genel olarak (f:37) dinî gerekçeler sunulmuştur. Türkçe ders kitaplarındaki etkinliklerin, ilgi çekici ve eğitici olmadığını ifade eden sınıf seviyesi çoğunlukla 7 ve 8 . sınıftır. Bu düşüncelerinin nedeni ise metin ve etkinliklerin ders kitabının dışında uygulamaya yönelik olmaması ve ders kitaplarının öğrencilerin kişisel özelliklerini değiştirme konusunda yeterli olmayacağı konusundaki ön yargıdır. "Ders kitaplarındaki metinler hem içerik hem de tür açısından ne kadar çeşitli tutulursa millî, manevî birçok değerin işlenmesi de o kadar etkili olur. Çünkü değer kazanımında gerek duyguya gerekse olay ve düşünceye dayanan türlerden yararlanılabilir" (Fırat ve Mocan, 2014: 40).

Günümüzde eğitim çağındaki öğrencilere benimsetilmek istenen değerler, güncel insanî değerler eğitimi programı uygulaması ders ortamında teknolojik imkânları kullanarak değerlerin özümsenmesi, çocuk ve ilk gençlik edebiyatı ürünleri ile değerlerin benimsenme isteğidir (Karacaoğlu, 2018: 23). Çünkü "Farklı becerilerin kullanıldığı bir ders ortamında öğrenciler doğrudan yaparak yaşayarak öğrendikleri için zamanla değer öğretiminde devamlılık sağlanabilir" (Kahya, 2018: 15).

YÖK Tez Merkezinden gelişmiş tarama ile yapılan alan araştırması sonucunda Türkçe ders kitaplarının değerlerle ilişkisine değinen 25 teze ulaşılmıştır. Bunlardan 17'si ortaokul, 8'i ise ilkokul Türkçe ders kitaplarında yer alan değerleri konu edinmiştir.

Tablo 8.

Değerler ile Türkçe Ders Kitapları Arasındaki Illişkiyi Inceleyen Tez Çalışmaları

\begin{tabular}{l|c|c}
\hline Tez Adı & Yıl & Tez Türü \\
\hline $\begin{array}{l}\text { Ilköğretim 1. kademe Türkçe ders kitaplarında değerlerin } \\
\text { incelenmesi }\end{array}$ & 2005 & Yüksek Lisans \\
\hline $\begin{array}{l}\text { Ilköğretim 7. sınıf Türkçe ders kitabındaki edebî metinlerin temel } \\
\text { evrensel değerleri içermesi bakımından incelenmesi }\end{array}$ & 2008 & Yüksek Lisans \\
\hline $\begin{array}{l}\text { Milli Eğitim Bakanlığı'nın hazırladığı 6. sınıf Türkçe ders kitabında yer } \\
\text { alan değerler üzerine bir araştırma }\end{array}$ & 2008 & Yüksek Lisans \\
\hline $\begin{array}{l}\text { Yapılandırmacı yaklaşıma göre ilköğretim 6 ve 7. sınıf Türkçe ders } \\
\text { kitaplarındaki değerlerin incelenmesi }\end{array}$ & 2009 & Yüksek Lisans \\
\hline $\begin{array}{l}\text { Ilköğretim 6. sınıf Türkçe ders kitaplarında yer alan sevgi temasının } \\
\text { değerler eğitimi açısından incelenmesi }\end{array}$ & 2010 & Yüksek Lisans \\
\hline $\begin{array}{l}\text { Ilköğretim birinci kademe Türkçe ders kitaplarındaki metinlerin } \\
\text { ilettiği değerler açısından incelenmesi }\end{array}$ & 2010 & Yüksek Lisans \\
\hline $\begin{array}{l}\text { 1997- 2005/sekiz yıllık kesintisiz eğitim süresince ilköğretim ikinci } \\
\text { kademe sınıflarında okutulan Türkçe ders kitaplarında ulusal ve } \\
\text { dinsel değerler }\end{array}$ & 2010 & Yüksek Lisans \\
$\begin{array}{l}\text { Türkçe ders kitaplarındaki okuma ve serbest okuma metinlerinin dini } \\
\text { ve ahlaki değerler açısından incelenmesi }\end{array}$ & 2012 & Yüksek Lisans \\
\hline $\begin{array}{l}\text { 8. sınıf Türkçe ders kitaplarındaki metinlerin değerler bakımından } \\
\text { incelenmesi }\end{array}$ & 2013 & Yüksek Lisans \\
\hline
\end{tabular}




\begin{tabular}{|c|c|c|}
\hline $\begin{array}{l}\text { 2012-2013 öğretim yılı ilköğretim 6. sınıf Türkçe ders kitaplarındayer } \\
\text { alan sevgi ve duygular temalarının değerler eğitimi açısından } \\
\text { incelenmesi }\end{array}$ & 2013 & Yüksek Lisans \\
\hline Ortaokul 8. sınıf Türkçe ders kitaplarındaki şiirlerde yer alan değerler & 2014 & Yüksek Lisans \\
\hline Ortaokul Türkçe ders kitaplarının değer iletimi açısından incelenmesi & 2015 & Yüksek Lisans \\
\hline $\begin{array}{l}\text { Ilkokul 4. sınıf Türkçe ders kitabı metinlerinin kültürel değerler } \\
\text { açısından incelenmesi }\end{array}$ & 2015 & Yüksek Lisans \\
\hline $\begin{array}{l}\text { Ikokul 4. sınıf öğrencilerinin Türkçe ders kitaplarında yer alan } \\
\text { metinlerdeki değerler ile ilgili algılarının incelenmesi }\end{array}$ & 2015 & Yüksek Lisans \\
\hline Ortaokul Türkçe ders kitaplarındaki etkinliklerin değerler eğitimi & 2018 & Yüksek Lisans \\
\hline $\begin{array}{l}\text { 5. sınıf Türkçe ders kitabındaki atasözlerinin değerler eğitimi } \\
\text { açısından incelenmesi }\end{array}$ & 2018 & Yüksek Lisans \\
\hline $\begin{array}{l}\text { Türkiye ve Kazakistan'da okutulan 6. sınıf Türkçe, Kazak edebiyatı ve } \\
\text { Rus edebiyatı ders kitaplarının değerler açısından incelenmesi }\end{array}$ & 2018 & Yüksek Lisans \\
\hline $\begin{array}{l}\text { Türkiye ve Kazakistan'da 5. sınıfta okutulan Türkçe, Kazak edebiyatı, } \\
\text { Rus dili ve edebiyatı ders kitaplarındaki metinlerin değerler } \\
\text { bakımından incelenmesi }\end{array}$ & 2018 & Yüksek Lisans \\
\hline Türkçe ders kitaplarındaki şiirlerin değerler bakımından incelenmesi & 2019 & Yüksek Lisans \\
\hline $\begin{array}{l}\text { Ortaokul Türkçe ders kitaplarındaki halk edebiyatı metinlerinin } \\
\text { değerler eğitimi açısından incelenmesi }\end{array}$ & 2019 & Yüksek Lisans \\
\hline $\begin{array}{l}\text { Ilkokul 1. sınıf Türkçe ders kitabı metinlerinin değerler eğitimi } \\
\text { açısından incelenmesi }\end{array}$ & 2019 & Yüksek Lisans \\
\hline $\begin{array}{l}\text { İlkokul 2. sınıf Türkçe ders kitabı metinlerinin değerler eğitimi } \\
\text { açısından incelenmesi }\end{array}$ & 2019 & Yüksek Lisans \\
\hline $\begin{array}{l}\text { Ilkokul 4. sınıf Türkçe ders kitabındaki metinlerin değerler eğitimi } \\
\text { bakımından incelenmesi }\end{array}$ & 2019 & Yüksek Lisans \\
\hline $\begin{array}{l}\text { Illkokul Türkçe ders kitaplarındaki öyküleyici metinlerin değerler } \\
\text { yönünden incelenmesi }\end{array}$ & 2019 & Yüksek Lisans \\
\hline $\begin{array}{l}\text { 6. sınıf Türkçe ders kitabında yer alan metinlerin değerler eğitimi } \\
\text { açısından incelenmesi ve öğretmen görüşleri bağlamında } \\
\text { değerlendirilmesi }\end{array}$ & 2019 & Yükse \\
\hline
\end{tabular}

Ortaokul Türkçe ders kitaplarının değerlerle ilişkisine değinen ilk tez 2005 yılında değişen Türkçe Öğretim Programına göre hazırlanan 7. sınıf Türkçe ders kitabındaki edebî metinlerin temel evrensel değerleri içermesi bakımından incelenmesi tezidir. Somuncu'nun (2008) tezinde 19 metin eğitsel açıdan değerlendirilip edebî, sanatsal ve evrensel değerler açısından incelenmiştir. Evrensel değer olarak 11 değer (adalet, ahlaklııı, ana babaya yardım ve aile içi dayanışma, barış, demokrasi, eşitlik, insan hakları, öz saygı, haklara saygı, sevgi, uygarlık) belirlenmiştir. Araştırma sonucunda 18 metinde evrensel değerler tespit edilirken yalnızca 1 metinde bu değerlerden herhangi birine rastlanmamıştır. Kitapta yer alan metinlerin evrensel değerler açısından düzey üstü metinler olduğu sonucuna ulaşılmıştır.

“Milli Eğitim Bakanlığı'nın hazırladığı 6. sınıf Türkçe ders kitabında yer alan değerler üzerine bir araştırma" adlı 2008 yılında yayımlanan tezde MEB Yayınları tarafından hazırlanan 6. Sınıf Türkçe Ders Kitabında yer alan on dokuz metin incelenmiş ve buradaki değerler tespit edilmiştir. Araştırma sonucunda saygı, sevgi, bağımsızlık, dini değerler ve vatanseverlik değerlerinin metinlerde fazlaca yer aldığı; sağlıklı olmaya önem verme ve hoşgörü değerlerinin ise tespit edilemediği ortaya konmuştur.

Yapılandırmacı yaklaşıma göre ilköğretim 6 ve 7. sınıf Türkçe ders kitaplarındaki değerlerin incelenmesi adlı tezde, Türk Millî Eğitiminin Genel Amaçları ile Illköğretim Kurumlarının Amaçlarından 
hareketle 73 değerin yer aldığı Değer İnceleme Formu oluşturularak 6 ve 7. sınıf Türkçe ders kitaplarındaki 48 metin, değerler bakımından incelenmiştir. Karagöz'ün (2009) çalışması sonucunda, ders kitaplarında en çok "sevgi, vatanseverlik, yardımseverlik, sabır, yaratııılık, çalışkanlık, mücadeleci olma, öğrenmeye meraklı ve istekli olma, çalışma bilincini taşıma, yapıcı eleştirel düşünceye sahip olma, bireysel/toplumsal sorunları tanıma ve çözebilme, araştırmacı olma ve okuma alışkanlığı kazanma" değerleri olduğu tespit edilmiştir. "Tarihî eserlerimizi koruma/sevme, ağırbaşlılık, bayrağa saygılı olma, kanunlara itaat etme, misafirperverlik" değerlerine ise yer verilmemiştir.

İlköğretim 6. sınıf Türkçe ders kitaplarında yer alan sevgi temasının değerler eğitimi açısından incelenmesi (Akyol, 2010) adlı tezde, iki farklı yayınevine ait 6. Sınıf Türkçe Öğretmen Kılavuz Kitaplarındaki sevgi temasının etkinlik ve kazanımları değerler eğitimine uygunluğu bakımından incelenmiştir. Araştırma sonucunda doğrudan sevgi değeriyle ilgili bir kazanımın olmadığı görülmüştür. "Temada, genel olarak değer kazandırmaya dönük etkinlikler, dil becerisi ve metin çözümlemesine dönük etkinliklerden daha azdır. Her iki ders kitabı da drama, rol yapma, empati etkinlikleri, tartışma, işbirlikçi öğrenme, örnek olay, eğitsel oyun gibi yöntem ve tekniklere daha çok ağırlık vermesi gerektiği belirlenmiştir" (Akyol, 2010).

8. sınıf Türkçe ders kitaplarındaki metinlerin değerler bakımından incelenmesi (Koç, 2013) tezinde 2006-2007 eğitim-öğretim yılında kullanılan 8. sınıf MEB Türkçe ders kitabındaki metinler ile 2011-2012 eğitim-öğretim yılında kullanılan 8. sınıf MEB Türkçe ders kitabındaki metinler değerler bakımından incelenmiştir. Araştırma sonucunda 2006-2007 eğitim-öğretim yılında kullanılan 8. sınıf MEB Türkçe ders kitabındaki metinlerde 36 (saygı, sorumluluk, vatanseverlik, sabır, doğruluk, dostluk, paylaşma, dayanışma, millet sevgisi, hayvan sevgisi, doğa sevgisi, memleket sevgisi, millî birlik, öz saygı, bağımsızlık, empati, barış, fedakârık, güven, bilimsellik, hediyeleşme, hoşgörü, çalışkanlık, istişare, din, kahramanlık, misafirperverlik, nezaket, kanaatkârlık, sanat, merhamet, ödüllendirme, vefa, takdir etme, tarih, Türk büyükleri) diğer ders kitabında 28 değere (sorumluluk, doğruluk, dostluk, dayanışma, paylaşma, öz saygı, öz güven, doğa sevgisi, memleket sevgisi, millet sevgisi, millî birlik, kültürel miras, Türk büyükleri, tarih, bağımsızık, misafirperverlik barış, bilimsellik, sanat, çalışkanlık, din, empati, nezaket, güven, vefa, kahramanlık, kanaatkârlık, merhamet) yer verildiği görülmüştür.

2012-2013 öğretim yılı ilköğretim 6. sınıf Türkçe ders kitaplarında yer alan sevgi ve duygular temalarının değerler eğitimi açısından incelenmesi (Atalay, 2013) tezinde, iki farklı yayınevine ait 6. Sınıf Türkçe Öğretmen Kılavuz Kitaplarında yer alan sevgi ve duygular temalarının hedefler, kazanımlar ve etkinlikler bakımından değerler eğitimine uygunluğu incelenmiştir. İncelenen her iki kitapta da doğrudan sevgi ve duygu değeri ile ilgili hiçbir kazanımın olmadığı sonucuna ulaşılmıştır. Belirtilen temalarda genel olarak değer kazandırmaya dönük etkinlikler, diğer etkinliklere oranla daha azdır.

Ortaokul 8. sınıf Türkçe ders kitaplarındaki şiirlerde yer alan değerler (Çapoğlu, 2014) tezinde 8. sınıflarda okutulan 7 tane Türkçe ders kitabındaki 33 şiir metni değerler eğitimi açısından incelenmiştir. 4 Türkçe öğretmeni, Güngör'ün (1993) değer sınıflandırmasından, Rokeach'ın (1968) araç değerler ve amaç değerler tablosundan, Yaman-Taflan-Çolak'ın (2009) ders kitaplarındaki değerler formundan yararlanılarak oluşturulmuş olan 28 adet değerin oluşturduğu bir listeden hareketle şiirleri incelemiştir. Her öğretmenin ortak olarak işaretlediği değerler tablolaştırılmıştır. Araştırma sonucunda 17 adet değer başlığıyla 104 tane değer bulunmuştur. En fazla işlenen değer insan sevgisidir, ardından Türk büyüklerine saygı ve doğa sevgisi gelmektedir. Bulunan diğer değerler; yardımseverlik, dürüstlük, sorumluluk, vatanseverlik, hayvan sevgisi, hoşgörülü olma, çalışkanlık, barış, kültürel ve milli bilinç, yurttaşlık, akılcılık, dil bilinci, duyarlıık değerleridir. Bulunmayan değerler ise büyüklere saygı, aile bilinci, toplumsal kurallara uyma, dini bilinç, tutumlu olma, cesaret, misafirperverlik, ahlak bilinci, görgü kurallarına uyma, demokrasi değerleridir.

Ortaokul Türkçe ders kitaplarının değer iletimi açısından incelenmesi (Aytekin, 2015) tezinde 2014 yılında okullarda okutulan MEB Yayınlarının ortaokul Türkçe ders kitaplarındaki değerler Schwartz'ın değerler ölçeğine (1992) göre çözümlenmiştir. Araştırmanın sonucunda göre en sık rastlanan değerler sırasıyla şöyledir: İlk sırada başarı ve geleneksellik bulunmaktadır, ardından hazcılık, güç, öz yönelim, evrenselcilik, uyarılım, uyma ve iyilikseverlik, son sırada güvenlik değerleri yer almaktadır. 5. sınıf ders kitabındaki değerler sırasıyla başarı, güç, uyarılım ve hazcılık, öz yönelim ve iyilikseverlik, evrenselcilik ve uyma, güvenlik gelenekselliktir. 6. sınıf ders kitabında hazcılık, 
evrenselcilik, güç ve başarı, geleneksellik, öz yönelim, iyilikseverlik ve uyma, güvenlik; 7. sınıf ders kitabında geleneksellik, güç, uyum ve öz yönelim, hazcılık, evrenselcilik, iyilikseverlik, uyma ve güvenlik, başarıdır. 8. sınıf Türkçe ders kitabında ise geleneksellik, başarı, hazcılık ve öz yönelim, güç, uyma, evrenselcilik ve uyma, uyarılım, iyilikseverlik ve güvenliktir. Schwartz değerlerinin en fazla 7. sınıf, en az ise 6. sınıf Türkçe ders kitabında yer aldığı tespit edilmiştir.

Ortaokul Türkçe ders kitaplarındaki etkinliklerin değerler eğitimi bakımından incelenmesi (Kahya, 2018) adlı tezde, 2017-2018 eğitim-öğretim yılında okutulan ortaokul Türkçe Ders Kitaplarındaki (MEB, Ez-De, Başak, Dörtel Yayınları) etkinlikler değerler eğitimi bakımından incelemiştir. Talim Terbiye Kurulunca belirlenmiş olan 27 değerin (sevgi, saygı, yardımlaşma/dayanışma, sorumluluk, adil olma, dürüstlük/doğruluk, dostluk, vatanseverlik, hoşgörü/duyarlılık, alçakgönüllülük, şefkat/merhamet, bağımsız ve özgür düşünebilme, aile birliğine önem verme, misafirperverlik, paylaşımcı olmak, özgüven, empati, çalışkanlık, iyimserlik, iyilik yapmak, fedakârlık, cesaret/liderlik, nazik olmak, estetik duyguların geliştirilmesi, temizlik, selamlaşma, kültürel mirasa sahip çıkma) etkinliklerde ne düzeyde yer aldığı araştırılmıştır. Araştırma sonucunda belirlenen değerlerin 5 . sınıfta 223; 6. sınıfta 214; 7. Sınıfta 78; 8. sınıfta 110 kere geçtiği tespit edilmiştir. Değerlerin sınıf seviyelerinde ve temalara göre belli bir plan dâhilinde yer almadığı sonucuna ulaşılmıştır.

5. sınıf Türkçe ders kitabındaki atasözlerinin değerler eğitimi açısından incelenmesi (Gerekten, 2018) adlı tezde, 2017-2018 yılında kullanılan MEB yayınlarına ait 5. sınıf Türkçe ders kitabındaki kök değerleri yansıtan atasözlerini belirlenmiştir. Ömer Asım Aksoy'un Atasözleri Sözlüğü incelenmiş kök değerleri yansıtan 552 atasözüne rastlanmıştır. Bu sözlükteki atasözlerinden 27'si ders kitabında tespit edilmiştir. Bunlardan 18 tanesinin 10 kök değeri de kapsadığı görülmüştür. Sonuç olarak atasözlerinin değerler eğitiminde etkili bir yöntem olduğu çıkarımında bulunulmuştur.

Türkçe ders kitaplarındaki şiirlerin değerler bakımından incelenmesi (Sarı, 2019) adlı tezde 2018-2019 yılında MEB yayınlarına ait ortaokul Türkçe ders kitaplarında yer alan 28 şiir Schwartz'ın değer sınıflandırması açısından incelenmiştir. Araştırma sonucunda en fazla gelenek; en az başarı ve uyma değerlerinin kullanıldığı tespit edilmiştir.

Ortaokul Türkçe ders kitaplarındaki halk edebiyatı metinlerinin değerler eğitimi açısından incelenmesi (Işık, 2019) tezinde 2005-2006'dan başlayarak 2018-2019 eğitim öğretim yılına kadar okutulan Türkçe ders kitapları (29 ders kitabı) incelenmiş, halk edebiyatı metinleri Talim Terbiye Kurulu'nun belirlemiş olduğu 27 değer ve MEB tarafından belirlenen 10 kök değer içerisinde taranmıştır. Araştırma sonucunda 29 ders kitabı içerisinde halk edebiyatına ait 120 metin tespit edilmiş ve bu metinlerde 318 değer bulunmuştur. Metinlerde en fazla yer alan değerler sevgi (64), vatanseverlik (44), dostluk (23), cesaret-liderlik (21), yardımseverlik (16) ve saygı (16) dır.

6. sınıf Türkçe ders kitabında yer alan metinlerin değerler eğitimi açısından incelenmesi ve öğretmen görüşleri bağlamında değerlendirilmesi (Derse, 2019) adlı tezde 2018-2019 yılında okutulan 6. sınıf Eksen Yayınları Türkçe ders kitabındaki metinler değerler eğitimi açısından incelenmiş ve öğretmen görüşleri bağlamında değerlendirilmiştir. Araştırma sonucunda 40 metinde 247 değer cümlesi tespit edilmiştir. Metinlerde en fazla yer alan değer sorumlulukken alçakgönüllülük ve estetik duyguların geliştirilmesi değerlerine hiç rastlanmamıştır. Öğretmen görüşleri incelendiğinde hoşgörü, sevgi ve yardımseverliğin öğretmenler için ön plana çıkan değerler olduğu, saygı değerinin ise metinlerde en fazla yer verilmesini istedikleri değer olduğu tespit edilmiştir.

\section{Sonuç ve Tartışma}

Bu çalışmada, ortaokul Türkçe ders kitaplarında yer alan Erdemler temasının kök değerlerle ilişkisi araştırılmıştır. Araştırma sonucunda Erdemler temasının, kök değerlerden sekizini içerdiği tespit edilmiştir. 5. sınıf ders kitabında dostluk, sabır, saygı, sevgi, yardımseverlik; 6. sınıfta adalet, dostluk, dürüstlük, sabır, saygı, sevgi, yardımseverlik; 7. sınıfta dostluk, dürüstlük, sevgi, yardımseverlik; 8. sınıfta ise adalet, dürüstlük, saygı, sevgi, sorumluluk, yardımseverlik kök değerlerine yer verilmiştir. Her sınıf seviyesinde yer alan değerler yardımseverlik ve sevgidir. Kök değerlerin en sıklıkla yer aldığı sınıf seviyesi 8. sınıftır. Toplamda 13 kez kök değere ait bulguya rastlanmıştır. Kök değer çeşitliliği bakımından en zengin sınıf seviyesi on kök değerden 7'sinin yer aldığı 6. sınıf seviyesidir. Öz denetim ve vatanseverlik kök değerlerinin Erdemler temasındaki hiçbir sınıf seviyesinde yer almadığı tespit 
edilmiştir. Diğer değerlerin dağııımı ise şöyledir: Adalet ( $f: 2)$, dostluk (f:4), dürüstlük (f:4), sabır (f:2), saygı (f:5), sevgi (f:8), sorumluluk (f:1), yardımseverlik (f:10). Bundan hareketle kök değerlerin metin ve etkinliklere dağılımında planlanmış bir değerler eğitiminin olmadığı sonucuna ulaşımıştır. "Değerlerin ders kitabı içerisine dağılımı homojen olmalıdır. Ders kitapları içerisindeki temalar oluşturulurken tema-değer uyumunun olmasına önem verilmelidir" (Gül, 2017: 76).

Kök değerlerin Erdemler temasındaki metin ve etkinliklerdeki oranlarına Şekil 1'de yer verilmiştir. Buna göre temada en fazla yüzdeliğe sahip olan değerler sırasıyla \%28 yardımseverlik, \%22 sevgi, \%14 saygı, \%11 dostluk ve dürüstlük, \%6 sabır, \%5 adalet, \%3 sorumluluk değerleridir. Yardımseverlik ve sevgi değerlerine daha fazla yer verilmesi, Erdemler temasının öğrencilere yardımsever ve sevgi odaklı bir kişilik eğitimi verdiğini ortaya koymaktadır.

Öğrencilerle (18 kız, 24 erkek) yapılan yarı yapılandırılmış görüşmelerde, ailenin değerleri kazandırmada çok etkili olurken Türkçe ders kitaplarının bu konuda yetersiz kaldığı sonucuna ulaşılmıştır. Bundan dolayı değerleri daha fazla içeren ve öğrencilerin bu değerleri içselleştirebileceği metinlerin seçilmesine dikkat edilmesi gerekmektedir. Etkinliklerde yer alan kök değerlerin uygulamaya dönük olmadığı tespit edilmiştir. Konfüçyüs'ün "Okudum, unuttum; gördüm, hatırladım; yaptım, öğrendim." düşüncesine uygun olarak etkinliklerin uygulanabilir olması öğrencileri daha çok güdüleyecek, değerlerin günlük yaşantıda nasıl yer aldığını göstermesi bakımından birer örnek teşkil edecektir. Öğretmenler de temaya canlılık katmak, öğrenciyi sürece dâhil edebilmek için uygulamaya önem vermelidir. Teknolojik alt yapısı bulunan sınıflarda metne hazırlık bölümlerinde öğrencileri güdüleyebilmek ve değerleri somutlaştırabilmek için kısa film, video, görsel vb. çoklu medya araçlarıyla tema desteklenmelidir.

Öğrencilerin arkadaş seçimini en fazla etkileyen değerlerin başında sevgi (f:39), dürüstlük (f:36), yardımseverlik (f:33) gelmektedir. Sınıf seviyesi yükseldikçe toplumsal kuralların daha az önemsendiği, büyüklere saygı ve sevginin azaldığı 7 ve 8 . sınıf öğrencilerinin verdiği cevaplar neticesinde belirlenmiştir. Bu nedenle bu sınıf seviyelerinde öz denetim, saygı, sevgi, vatanseverlik ve yardımseverlik değerlerine ağırlık verilmesi öngörülmektedir. Ebeveynler tarafından öğrencilere en çok saygı değerinin benimsetilmeye çalışıldığı tespit edilmiştir. Bunda sosyoekonomik, sosyokültürel, eğitim, çevre gibi faktörlerin etkili olduğu gözlemlenmiştir. Yine 7 ve 8. sınıf öğrencileri Türkçe ders kitabındaki metin ve etkinliklere güdülenme konusunda diğer sınıf seviyelerinin gerisinde kalmaktadır. Bu konuda öğrenciler, seçilmiş olan metin ve etkinliklerin ilgi çekici, merak uyandırıcı, güncel, uygulanabilir olmaması; öğretmen faktörü gibi sebepleri öne sürmüştür.

Öğrencilerin çoğu (f:37) ahlâkın dinî sebeplerden dolayı gerekli olduğunu düşünmektedir. Bundan dolayı öğrencilerin üzerinde inancın ve çevrenin daha etkili olduğu, metin ve etkinliklerde verilmeye çalışılan değerler eğitiminin öğrencileri daha az etkisi altına aldığı varsayımında bulunulmaktadır.

Araştırma sonucunda bazı kök değerlerin daha geri planda kaldıkları (öz denetim, vatanseverlik, adalet, sabır, sorumluluk) bazılarının ise (yardımseverlik, sevgi, saygı) sık şekilde metin ve etkinliklerde yer aldığı görülmektedir. Bunların yanı sıra kök değer olmamasına rağmen cömertlik, birlik, hoşgörü, alçak gönüllülük ve güler yüzlülük değerleri de metinlerde sıklıkla yer alan değerlerdir. Öğretim programında yer alan kök değerlerin hem kendi başlarına hem ilişkili olduğu alt değerlerle hem de öteki kök değerlerle birlikte ele alınarak hayat bulacağı ifade edilmektedir fakat bu değerlerin ne sıklıkta ders kitaplarında yer alacağıyla ilgili takip yapılmamaktadır. Öyle ki araştırma sonucunda Erdemler temasında, kök değerlerden ikisine yer verilmediği görülmüştür. Araştırmadaki sınırlılığın Erdemler teması olmasından dolayı diğer temalarda kök değerlerden hangilerinin olup olmadığı soru işaretidir. Bu sebeple Türkçe Öğretim Programı'nda yer alan temalarda hangi kök değer ya da alt değerin işlenmesi gerektiği belirtilmelidir. Bu sayede belli başlı ya da sürekli olarak tekrarlanan değerler yerine, göz ardı edilen değerlere de söz hakkı tanınacak; öğrencilerin her değerin önemini kavraması ve uygulayabilme imkânı bulması sağlanacaktır. Erdemler temasında yer alan değerlerin, öğrencilerin günlük yaşantılarında kalıcı öğrenmelerin oluşmasına zemin hazırlaması ve daha kapsamlı bir ölçme değerlendirmeye tâbi tutulabilmesi için kitaptaki etkinliklerin yeterli olmadığı yapılan görüşmeler neticesinde tespit edilmiştir. Okul içi ve dışında gerçekleştirilebilecek, öğrencilerin etkin rol oynadığı, farkındalık kazanabilmelerini sağlayan çeşitli etkinlik ve uygulamalara yer verilmelidir. Bu noktada 
2018-2019 eğitim öğretim yılında okutulan Türkçe ders kitaplarındaki Erdemler temasında yer alan metinler için bazı örnek etkinlik ve uygulamalar şunlar olabilir:

- Gülü İncitme Gönül metni sonrasında doğa sevgisini ve bir bitki yetiştirirken sabırlı olmanın önemini gösterebilmek için Tarım ve Orman Bakanlığı Orman İşletme Genel Müdürlükleriyle iletişime geçilip okullara yönelik olarak yapmış oldukları etkinliklere dâhil olunması,

- saygı değeri için Emine Teyzenin Çilek Reçelleri metninden sonra huzurevine ya da muhtarlıklarla iş birliği yapıp yakın çevrede bulunan yaşılıara ziyaretlerin gerçekleştirilmesi,

- yardımseverlik değerinin işlendiği Adsız Çeşme metninden sonra öğrencilerin karşııısız iyilik yapmanın önemini görebilmeleri için yardıma intiyaç duyan bir okulla kardeş okul projesi gerçekleştirilip eksikliklerinin giderilmesi,

- Yunus Emre'nin Mezarları metninden sonra okul içerisinde herhangi bir etkinlik, pano çalışması vb. gerçekleştirilip görev dağılımı yapılarak olabildiğince fazla öğrenciye sorumluluk verilmesi,

- dürüstlük değerine dikkat çekmek amacıyla Kızgın Bir Lira metni sonrasında bu konuyla ilgili kısa film ya da çizgi filmlerin imkânlar dâhilinde seyrettirilmesi,

- Kaplumbağayla îki Ördek metni sonrasında hayvan dostlarımızın yiyecek, su, barınak gibi ihtiyaçlarının karşılanması,

- vatanseverlik değeri için bu konuyla ilgili tiyatro, oratoryo vb. yaptırılması,

- adalet ve öz denetim değeri için kantin, okul bahçesi veya oyun alanlarında sergilenmek üzere pankart, afiş, döviz çalışmaları yapılması.

Aynı zamanda değerleri kazandırmada teknoloji desteği de alınmalıdır. Bu konuda SEDEP'in (Selçuklu Değerler Eğitimi Programı) değerler eğitimine yönelik olarak hazırlamış olduğu çizgi filmler, on kök değerden sekizine yer vermesi ve eğlendirerek öğretmesi bakımından oldukça kıymetlidir. 5 ve 6. sınıf ders kitapları Erdemler temasındaki dinleme metinlerinin bu çizgi filmlerden seçilmesi önerilmektedir. Öğrencilerin uygulama sonrası görüşlerini içeren bölümler de metinlerden sonra kitaba dâhil edilmelidir.

Yapılan alan taramasında değerler eğitiminin Türkçe ders kitabıyla ilişkisini inceleyen 25 teze ulaşılmıştır. Bu taramada değerler eğitimiyle ilgili yapılan tez çalışmalarının son yıllarda, özellikle 2018 'den itibaren arttığı gözlemlenmiştir. Bunun nedeninin değişen öğretim programında değerler eğitimine verilen önemin artarak 10 kök değerin belirlenmesi ve bu kök değerlerin eğitim programının birer parçası olduğunun vurgulanmasıdır. Tezlerin içeriklerinden hareketle ders kitaplarında geçmişten günümüze en fazla yer alan kök değerlerin saygı, sevgi, vatanseverlik, yardımseverlik ve sorumluluk olduğu sonucuna varılmıştır. MEB tarafından belirlenen kök değerler listesinden önce hazırlanan tezlerde ise "Evrensel değerler, Erol Güngör'ün (1993) değerler sınıflandırması, Rokeach'ın araç değerler ve amaç değerler tablosu (Rokeach, 1973; Akt. Akbaş, 2004). Schwartz'ın değerler ölçeği (Schwartz, 1992; Akt. Keskin, 2016) Talim Terbiye Kurulunun değerler tablosu" ölçüt alınarak ders kitaplarındaki değerler incelenmiştir. Hazırlanan tezlerin yararlandıkları kaynakların çoğunun yabancı menşeli olduğu tespit edilmiştir.

Öğretmenlerin değerler eğitiminde en çok işbirliğine dayalı öğrenme tekniği ve yaratıcı drama yöntemlerini kullandığı görülmektedir. Öğrencilerin değerlere daha çok dikkatini çekebilmek için tartışma, drama, benzetim tekniği, rol yapma gibi farklı yöntem ve teknikleri kullanmasının öğrencilerin değerleri algılamasında ve değerlere olan tutumunda büyük bir etkisi vardır. Öğrencilerin temada yer alan değerler hakkında ne gibi donanımlara sahip olduğu, temanın farklı bir etki yaratıp yaratmadığı, okul içi ve dışındaki hareketlerinde gözlemlenebilir değişikliklerin meydana gelip gelmediğine yönelik olarak ölçme ve değerlendirme genellikle gözlemle sınırlı tutulmaktadır. Akranların, ailelerin ve diğer öğretmenlerin görüşleri de ölçme değerlendirme sürecine dâhil edildiği zaman ölçme değerlendirmede daha doğru veriler elde edilebilmektedir. Aynı zamanda öğretmen ve ailelerin rol model olması, değerlerin kazandırılmasında büyük etki sahibidir. Değerler eğitimine geniş bir zaman ayrılarak aileleri de kapsayan bir boyutuyla derinlemesine kazandırılması gerekir. Bu nedenle veli-okul iş birliği çok önemlidir. "Aile seminerleri ile anne ve babalar okullarda toplanarak temelden bir sistem oturtulabilir" (Gökalp vd., 2016: 100). Değer kazanımının, öğrencilerin toplumda bir yer edinebilmeleri için gerekli olduğu fark ettirilmelidir. "Amaçları sadece okulun maddi ihtiyaçlarını gidermek olarak düşünülen ya 
da uygulamaları itibarıyla öyle görünen okul-aile birlikleri" (Ergin ve Karataş, 2014: 44) bu sürecin içerisine dâhil edilerek aileler için uzman kişilerce konferans düzenlenmesine aracı olabilir. "Programda kazandırılması amaçlanan kök değerler, değerler eğitiminde izlenebilecek yöntemler ve bu yöntemlerin uygulanışı hakkında öğretmen adayları ve öğretmenler eğitilmelidir" (İşcan, 2007: 313).

Türkçe Öğretim Programı'nda yapılan inceleme neticesinde değerlere yönelik hiçbir kazanımın yer almadığı görülmektedir. "Program değerlerin ayrı bir öğrenme alanı veya bir program olarak görülemeyeceğini dile getirmekte bu nedenle de kazanımlarda değerlere yönelik ifadelere yer verilmediği düşünülmektedir" (Ergül, 2019: 104). "Programlarda verilen bu değerlerin kazanım olarak verilmemesi bütün okullarda tutarlı bir değerler eğitimi verilmesini engellemektedir" (Elbir ve Bağcı, 2013: 1323). Metinlerin içerisinde aynı anda birden fazla kök değere yer vermektense bütün metinlere kök değerlerin eşit düzeyde dağıtılması önerilmektedir. Seçilecek metinlerde çocuk edebiyatı metinlerinde dikkat edilecek kriterler de göz ardı edilmemeli, kazandırılması istenen değerler aleni şekilde metinde yer almamalıdır. "Temel öğrenme alanları gözetilerek hangi sınıf seviyesinde, hangi değerlerin aktarılacağı belirlenmelidir" (Türkben, 2019: 522).

Kök değerlerin, ilişkili olabileceği alt değerlerle birlikte ele alınabileceği Türkçe Öğretim Programında belirtilmiştir. Yine programın Temalar ve Konu önerileri başlığı altında da Erdemler temasında yer alması beklenen her konunun bir değer içerdiği görülmektedir. Dolayısıyla ders kitabı yazarlarının seçilen metinlerde öğretim programında ifade edildiği üzere hareket etmesinin daha sistemli bir değerler eğitimini beraberinde getireceği düşünülmektedir.

\section{Kaynaklar}

Akbaş, O. (2004). Türk milli eğitim sisteminin duyuşsal amaçlarının ilköğretim II. kademedeki gerçekleşme derecesinin değerlendirilmesi. (Yayınlanmamış doktora tezi), Gazi Üniversitesi, Ankara.

Akyol, Ş. (2010). ilköğretim 6. sınıf Türkçe ders kitaplarında yer alan Sevgi temasının değerler eğitimi açısından incelenmesi. (Yayınlanmamış yüksek lisans tezi), Onsekiz Mart Üniversitesi, Çanakkale.

Ceylan, S., Duru, K., Erkek, G., Pastutmaz, M. (2018). Ortaokul ve imam hatip ortaokulu 6. sınıf Türkçe ders kitabı. Z. Batur ve S. Ceylan (Ed.) Ankara: MEB Yayınları.

Cihan, N. (2014). Okullarda değerler eğitimi ve Türkiye'deki uygulamaya bir bakış. Turkish Studies, 9(2), 429-436.

Deniz, K. ve Karagöl, E. (2018). Değerler eğitimi açısından ortaokul Türkçe ders kitapları. Karaelmas Eğitim Bilimleri Dergisi, 6(2), 244-255.

Ecerkale, N. ve Bayrak, Ö. (2018). Türkçe 7. sınıf ders kitabındaki metinlerin değerler bağlamında incelenmesi. The Journal of International Lingual Social and Educational Sciences, 4(2), 277287.

Elbir, B. ve Bağcı, C. (2013). Değerler eğitimi üzerine yapılmış lisansüstü düzeyindeki çalışmaların değerlendirilmesi. Turkish Studies, 8(1), 1321-1333.

Ergin, E. ve Karataş, S. (2014). Öğretmenlerin değerler eğitimi hakkındaki görüşleri: Bir durum çalışması. Journal of Educational Science, 2(2), 33-45.

Ergül Özkul, Z. (2019). Haldun Taner'in öykülerinde tespit edilen değerlerin Türkçe Öğretim Programında (1-8. Sınıf) yer alan kök değerlerle uyumu. (Yayımlanmamış yüksek lisans tezi), Muğla Sıtkı Koçman Üniversitesi, Muğla.

Fırat, H. ve Mocan, A. (2014). Türkçe ders kitaplarındaki hikâyelerde yer alan değerler. Türkiye Sosyal Araştırmalar Dergisi, 3, 25-49.

Gül, M. (2017). Türkçe ders kitabındaki metinlerin (5. sınıf) değerler eğitimi yaklaşımıyla incelenmesi. Erciyes Journal of Education, 1 (1), 59-78.

Güven, A. Z. (2014). Değerler eğitimi ve Türkçe derslerinde değerlerin kullanımı. Konya: Palet Yayınları.

Haykır, H., Kaplan, H., Kıryar, A., Tarakcı, R., Üstün, E. (2018). Ortaokul ve imam hatip ortaokulu 5. sınıf Türkçe ders kitabı. B. Bayram ve E. Aktaş (Ed.) Ankara: MEB Yayınları. 
İşcan, D. (2007). Illköğretim düzeyinde değerler eğitimi programının etkililiği. (Yayınlanmış doktora tezi), Hacettepe Üniversitesi, Ankara.

Kahya, A. (2018). Ortaokul Türkçe ders kitaplarındaki etkinliklerin değerler eğitimi bakımından incelenmesi. (Yayımlanmamış yüksek lisans tezi), Uşak Üniversitesi, Uşak.

Karacaoğlu, H. (2018). Dijital hikâyelerin Türkçe dersi değerler eğitimine yönelik etkisinin incelenmesi. (Yayımlanmamış yüksek lisans tezi), Erciyes Üniversitesi, Kayseri.

Karataş, S., Gökalp, H., Tüzün, F. \& Korkut, G. (2016). Değerler eğitimi etkinliklerine ilişkin öğretmen görüşlerinin değerlendirilmesi: Bir durum çalışması. Z. Kaya, E. Demiray (Ed.), Yaşam Boyu Eğitim Dünya Kongresi Kitabı (ss. 91-108). Antalya.

Karatay, H. (2011). Karakter eğitiminde edebi eserlerin kullanımı. Turkish Studies, 6(19), 1439-1454.

Keskin, Y. (2016). Değer sınıflaması üzerine aksiyonel bir deneme. Turkish Studies, 11(3), 1485-1510.

Kır, T., Kırman, E., Yağız, S. (2018). Ortaokul ve imam hatip ortaokulu 7. sınıf Türkçe ders kitabı. E. Kırman (Ed.) Ankara: MEB Yayınları.

MEB (2018). Türkçe dersi (1-8. sınıflar) öğretim programı. 20.02.2019 tarihinde http://mufredat.meb.gov.tr/ProgramDetay.aspx?PID=332 adresinden alınmıştır.

Mete, G., Karaaslan, M., Kaya, Y., Ozan, Ş., Özdemir D. (2018). Ortaokul ve imam hatip ortaokulu 8. sınıf Türkçe ders kitabı. I. Erdem (Ed.) Ankara: MEB Yayınları.

Mutlu, H. ve Dinç, S. (2019). 6. sınıf Türkçe ders kitabında yer alan temalardaki metinlerin kök değerlerle ilişkisi. Ana Dili Eğitimi Dergisi, 7(4), 1048-1062.

Topal, Y. (2019). Değerler eğitimi ve on kök değer. Mavi Atlas, 7(1), 245-254.

Türkben, T. (2019). Türkçe ders kitaplarındaki metinlerin ilettiği değerler açısından incelenmesi. Ana Dili Eğitimi Dergisi, 7(3), 508-526.

Yıldırım, A. ve Şimşek, H. (2018). Sosyal bilimlerde nitel araştırma yöntemleri. Ankara: Seçkin Yayınları.

\section{Introduction}

\section{Extended Abstract}

There exist thirteen particular themes (three of which are compulsory), which should be included in the Turkish Language Lesson Syllabus under the title of Themes and Topic Recommendations. From the mandatory themes, it is observed that each topic in the subject of Virtues contains a value, whereas two values cover the essential value of patriotism only. Because of its compulsory nature, the theme is considered to be followed on every class level. It is also thought that the incorporation of the virtue theme may provide a more systematic value teaching when topic distribution among the themes and the relationship between values and virtues are taken into account. For this reason, it is necessary to examine every each text and activity (under the theme of Virtues) within this context, identify the teaching of the theme by Turkish language teachers, how the texts and activities are perceived by students and to what extent the activities overlap with praxis. This study examines the relationship between the textual and skill-based activities in the theme of Virtues and the ten basic values of "justice, friendship, honesty, self-control, patience, respect, love, responsibility, patriotism and philanthropy" (Turkish Language Education Syllabus, 2018:4).

\section{Method}

The research was carried out within the scope of the document review, which is one of the qualitative research patterns. The relationship between the texts and activities in the Virtues theme (12 reading, 4 listening texts) and the ten fundamental values determined in the Turkish Education Program (2019) as "justice, friendship, honesty, self-control, patience, respect, love, responsibility, patriotism, and benevolence" was examined with the research. 18 female and 24 male students studying at Istanbul Pendik Nurettin Topçu Imam Hatip Secondary School were selected randomly and semi-structured interviews were held with these students. With this research, answers to the following questions were investigated:

1. How is the distribution of fundamental values in the Virtues theme?

2. What values are aimed to be taught to the students in the theme? 
3. Are the texts and the activities which take place in fundamental values sufficient to gain those values?

4. How often are fundamental values mentioned in the activities?

5. Can the fundamental values in the texts be related to real life?

In the research, criteria sampling, one of the purposeful sampling methods, was used. The theme of Virtues, which is included in the MEB Publications Middle School and Imam Hatip Secondary School Turkish Coursebooks as a compulsory theme, has been examined by taking the criteria of Turkish Course Curriculum Fundamental Values. Document control, semi-structured interview, and field screening were used to make the study valuable by controlling the results obtained in the research in several ways. A field scanning was conducted on the values education, and the Virtues theme and deficiencies and expert opinions were determined. The fundamental values in the Turkish Curriculum (2019) were used while conducting the document analysis. Data were collected through document review in the research. The collected data were analyzed according to descriptive analysis and content analysis. The texts and activities in the Virtues theme have been analyzed according to the Turkish Language Curriculum Fundamantal Values list. The texts and activities in the theme were examined, and codings were made within the scope of content analysis. Two themes, namely "values" and "fundamental values," were determined as a result of the codings. Semi-structured interviews with 42 students were transcribed, the data were examined and coded, specific themes were reached, and the data were interpreted in the findings section. Dissertations which investigate the relationship between Turkish coursebooks and values education were investigated for field scanning. It has been determined that how the values are reflected in the coursebooks from past to present and which values are frequently included in the books.

\section{Result and Discussion}

As a result of the research, it is determined that the theme of Virtues includes eight fundamental values. The fundamental values given in the coursebooks according to their levels are as follows: friendship,patience, respect,love,helpfulness in fifth grade;justice, friendship, patience, respect, love, helpfulness in the sixth grade; friendship, honesty,love,helpfulness in the seventh grade;justice,honesty, respect, love,responsibility, helpfulness in the eighth grade. The values which take place in every class level are helpfulness and love. The 8th grade is the class level in which fundamental values often take place. The findings of fundamental values are encountered for thirteen times in total. Self-control and patriotism values are not determined in the Virtues theme at any class level. The frequency of the other values is as follows : Justice(f:2), friendship(f:4), honesty (f:4), patience (f:2), respect (f:5), love(f:8), responsibility (f:1), helpfulness (f:10). Based on these findings, it is concluded that there is no planned value education in the distribution of texts and activities. The values that have the highest percentage in the theme are $\% 28$ helpfulness, $\% 22$ love, $\% 14$ respect, $\% 11$ friendship and honesty, $\% 6$ patience, $\% 5$ justice , $\% 3$ responsibility, respectively. The primary values that affect students' choice of friends are love(f:39), honesty(f:36), helpfulness(f:33) As a result of the responses given by 7 th and 8 th-grade students it was determined that social rules were less important and respect and love for adults decreased as the grade level increased. Therefore, it is envisaged to focus on self-control, respect, love, patriotism and helpfulness values at these class levels. It is determined that parents try to adopt the most respect value for students. It was observed that factors such as socioeconomic, sociocultural, education, and environment were effective here. Again, the 7th and 8th-grade students fall behind other grade levels in terms of motivation for the text and activities in the Turkish coursebook. The reasons stated by students in this regard are teacher factor and the selected texts and activities' being not interesting,appealing, up-to-date, and applicable. Most of the students think that morality(f:37) is necessary for religious reasons. Hence, it is assumed that belief and environment are more effective on students thanvalues education given in text and activities.

In the field survey, 25 dissertations were examined and analyzed within the relationship between values education and the Turkish coursebook. In this field screening, it was observed that studies on values education increased in the last years. Based on the content of the dissertations, it has been concluded that the most important values in the coursebooks from past to present are 
respect, love, patriotism, helpfulness, and responsibility. In the dissertations prepared before the list of fundamental values specified by Ministry of National Education," the criteria of Universal values, Erol Güngör's (1993) classification of values, Rokeach's (1973) vehicle values and purpose values table, Schwartz's values scale, Board of Education Board's value criteria" were taken as criteria and the values in the coursebooks were examined. It has been determined that most of the sources used by the prepared dissertations are of foreign origin.

Ek

\section{Ek-1. Görüşme Soruları}

Öğrenci Görüşme Soruları

Arkadaş seçimlerinizde hangi özellik ve değerler sizin seçiminizi etkilemektedir?

Büyüklerinizin öğütlerini sıkıcı mı bulursunuz, önemser misiniz?

Ebeveynleriniz size hangi konularda uyarılarda bulunur?

Niçin ahlâklı olmamız gerektiğini düşünüyorsunuz?

Toplumsal kurallara uygun hareket eder misiniz?

Türkçe ders kitaplarını değerleri kazandırmada yeterli buluyor musunuz? 